\title{
Overtime risk preference and its determinants: Evidence from Indonesia
}

\author{
Muhammad Yusuf Indra Purnama* | Linggar Ikhsan Nugroho \\ Faculty of Economics and Business, Universitas Sebelas Maret
}

\begin{abstract}
This research aims at examining the potential determinants of overtime risk preference in Indonesia-one of the most diverse countries in the world. We used household and individual data as well, taken from the fourth and fifth wave of the Indonesia Family Life Survey (IFLS). The risk aversion of the individual was observed and elicited using hypothetical gambling questions. From the result of Ordinary Least Square (OLS) estimation, we find preliminary evidence that there is a decrease in risk-aversion among individuals over time. However, there is little evidence that catastrophe will alter risk choice as a proxy for a significant life event. Furthermore, our empirical finding also revealed that risk tolerance is motivated not only by demographic factors but also by the education level and individual's time preference.
\end{abstract}

Keywords: Preference, risk aversion, overtime, Indonesia

\section{Introduction}

In many settings, risk preference is an essential issue from individual investment or occupational choice decisions to government choices about policies that affect environmental, industrial or health risks, are related to this preference. Risk preferences are mostly tested with real impact using surveys or incentivized games. Assessing the different methods for calculating individual risk preference reveals that the best approach depends on the question being posed and the target population of the study. Notably, the high standard in incentivized games by economists cannot surpass surveys in all settings (Eckel, 2019).

If preferences are consistent behavioral characteristics, then they should be stable not only over circumstances but also overtime. Nonetheless, research from several studies argues that risk perceptions will shift in many ways over time (e.g. Schildberg-Hörisch (2018), Sakha (2019)). Firstly, exposure to a different environment can alter preferences slowly. Second, a change in risk preferences may occur in the wake of a significant life event, such as a natural disaster or a financial crash, and short-term and long-term effects may also differ.

Further evidence suggests that individuals who have recently experienced a flood or earthquake show higher levels of risk aversion. Experiencing a natural disaster leads people to believe that they are now facing a higher risk of a future catastrophe (Cameron and Shah, 2015). They conclude that changes in the perception of risk cause people to take less risk. Yet the opposite is reported by others. For example Eckel et al. (2009) find evacuees displaying more risk-loving behavior the context of hurricane setting in the United States.

A recent class of economic models in the field of self-control claim that economic decisions are influenced by the interaction of dual systems. There is consist of long-run system and short-run system (Alós-Ferrer and Strack, 2014). Several such models specifically tackle under-risk decisionmaking. In particular, at the expense of the risk-neutral long-run self, lower current levels of self-control capacity are believed to change the balance of power in favor of the risk-averse. Lower self-control is

\footnotetext{
${ }^{*}$ Corresponding author at Jl. Ir. Sutami No.36A, Pucangsawit, Kec. Jebres, Kota Surakarta, Jawa Tengah 57126. Email: myindra.p@gmail.com
} 
therefore expected to cause higher risk aversion for stakes within a given range (see, e.g. Fudenberg, Levine and Maniadis (2014) and Levin et al., (2007)).

In IFLS, it is possible to calculate self-control by using a series of questions in the "Time Preference" section. The respondents were asked to answer a series of questions about winning potential money in a lottery. There are two games in this section that vary in the time the respondent gets the money (in 1 year in Game 1 and 5 years in Game 2). We then developed a certain time preference measure with values ranging from 1 (very patient) to 5 (very impatient).

The contribution of our paper is to empirically measure risk preferences frequently over a long period with the same individuals in one of the world's most diverse countries. Indonesia, with more than 240 million people with a broad variety of ethnic, regional and economic backgrounds, is an important subject for the analysis of risk preference. Similar work was carried out for Indonesia by Cameron and Shah (2015) and Sanjaya (2013). Nevertheless, their contribution is limited to the impact of natural disasters on risk preference in rural areas (especially East Java) and only covers the IFLS data from 2007.

\section{Method}

\subsection{Data, variable construction, and descriptive statistics}

To assemble risk-aversion variables, we used data from the Indonesian Family Life Survey (IFLS). RAND carried out the IFLS in partnership with local research institutions in Indonesia and is available free of charge on the RAND website. The IFLS respondents come from just 13 (out of 26) provinces in Indonesia, but they represent about 83 per cent of Indonesia due to the dense distribution of the population. The IFLS' first wave was in 1993, and it was continued in 1997, 2000, 2007 and 2014.

The IFLS consists of two parts, namely household and community. The household part measures individual's and household's life such as consumptions, welfare, and health level, while the Community part measures community/village life, such as the availability of health and education facilities. Although the IFLS is a dataset panel rich in information about behavior of households and individuals, it is unfortunate that it only addresses risk-taking topics in the last two rounds (IFLS4 and IFLS5).

In IFLS4 and IFLS5, under the "Risk and Time Preference" section, specific questions can be used to measure risk aversion. There are two games for this segment: Game 1 and Game 2, where they differ only in the amount of hypothetical money involved. The respondent will be asked to choose between two games, and if he/she chooses the risky one, he/she will move on to the next question (which gives different payoff). In any question there is an option "Don't Know" which can be used to rule out respondents who don't understand the question. Here is an example of the gamble (See Appendix for a full set of questions and definitions):

In Option 2, you have an equal chance of receiving either Rp1.6 million per month or Rp400 thousand per month, depending on how lucky you are. [On the other hand,] Option 1 guarantees you an income of Rp800 thousand per month. Which option will you choose?

Several methods have been applied to construct risk aversion from the IFLS dataset. First, risk aversion developed by order based on the risk-choice degree (Cipollone and D'Ippoliti, 2011). Second is the binary variable, which simplifies either risk-loving or risk-averse choice (Cameron and Shah, 2015). The third approach is based on Absolute Risk Aversion (ARA) of Arrow-Pratt index (Permani, 2011).

The first and second approach required us to make two regressions based on Game 1 and Game 2 due to its construction. The first approach is possibly the second-best choice, although the coefficient is difficult to interpret if we use standard OLS to estimate. The second method is the simplest in its construction, but it fits the experimental approach of Cameron and Shah (2015) since the ordinal variable is not used in the main part of their paper.

The third approach generally offers the best alternative because of the following reasons: First, ARA took information from both Game 1 and Game 2. Second, this measure is also linked directly with the theoretical underpinning of risk aversion (Pratt, 1964). Third, as can be seen in equation (1) below, 
$A R A$ is a continuous, nonlinear variable that offers more variance in risk aversion. Hence, in regression, we used ARA where a higher value implies a more risk-averse decision.

$A R A$ is estimated based on the expected utility of the participation of an individual in the gamble (also after considering his / her initial wealth endowment). Taking the Taylor second-order expansion of the predicted utility around the initial wealth endowment resulted in the following formula (where $Z_{h}$ is the high payoff ( $R p 1.6$ million in the above example) $a Z_{l}$ is the low payoff ( $R p 400$ thousand)):

$A R A=\frac{Z_{h}+Z_{l}}{Z_{L}^{2}+\left(Z_{h}-Z_{l}\right)^{2}+Z_{l}\left(Z_{h}-Z_{l}\right)}$

Based on ten questions on risk preference (see appendix), we found eight possible payoff combinations of $Z_{h}$ and $Z_{l}$ which translated into eight values of $A R A$. The frequency distribution of $A R A$ both in 2007 and 2014 sample are skewed toward those who are very risk-averse $(A R A=0.25)$ but tend to decrease on the extreme risk-averse frequency distribution value (see Figure 1).

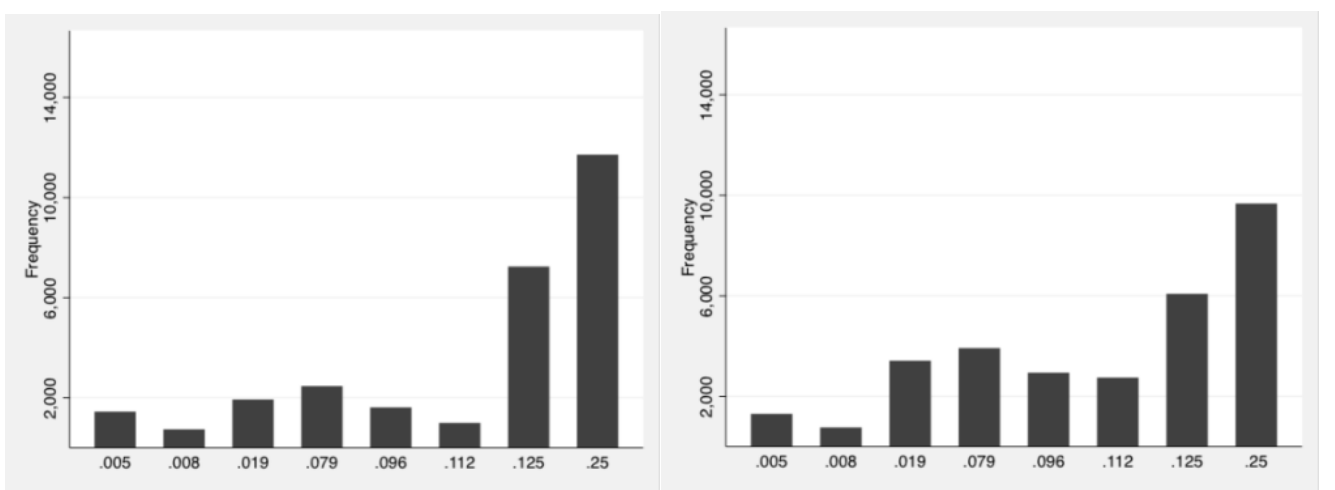

ARA 2007

ARA 2014

Figure 1: Absolute risk aversion frequency distribution between 2007 and 2014

Table 1 below shows that the cross-correlation between $A R A, R A, R L 1$, and $R L 2$ in our full sample is quite strong (particularly between $A R A$ and $R A$ that has -0.77 correlation coefficient). As regards potential alternative of risk aversion measurement, the mean for $R L 1$ is 0.18 (SD 0.38) and 0.05 (SD 0.21 ) for $R L 2$, suggests that the overwhelming majority of respondents are risk averse.

Table 1. Cross-correlation of various measure of risk aversion

\begin{tabular}{lrrrr}
\hline & ARA & $R A$ & $R L 1$ & $R L 2$ \\
\hline$A R A$ & 1 & & & \\
$R A$ & -0.77 & 1 & & \\
$R L 1$ & -0.48 & 0.78 & 1 & \\
$R L 2$ & -0.35 & 0.57 & 0.28 & 1 \\
\hline
\end{tabular}

Table 2 provides descriptive statistics of individual and household characteristics of our sample. For the full sample, respondents are, on average, 37 years old. Around 53\% of the respondents are female. Approximately $64 \%$ are living in the urban area, with $71 \%$ has been married. Over the years, the assets ownership value of the household increases slightly, while the number of disasters experienced increases.

We find several differences between 2007 and 2014 sub-sample. The repeated sub-sample variable differs in terms of risk preference, physical characteristics (height and weight), temporary shock (number of disaster sex experienced, and financial assistance received), and educational levels. There is also evidence of the increasing number of urbanizations, people moving from rural to urban area. Time preferences also reported decreases, meaning that the individual tends to be more patient over the years. 
Table 2. Descriptive statistics

\begin{tabular}{|c|c|c|c|c|c|c|c|c|c|c|}
\hline \multirow{2}{*}{ Variable } & \multicolumn{3}{|c|}{ Full sample } & \multicolumn{3}{|c|}{ Year $=2007$} & \multicolumn{3}{|c|}{ Year $=2014$} & \multirow{2}{*}{ t-test } \\
\hline & Obs. & Mean & S.D. & Obs. & Mean & S.D. & Obs. & Mean & S.D. & \\
\hline \multicolumn{11}{|l|}{ Individual Physical characteristics } \\
\hline ARA & 58,986 & 0.14 & 0.09 & 28,141 & 0.15 & 0.09 & 30,845 & 0.13 & 0.09 & 0.00 \\
\hline RA & 58,986 & 0.75 & 1.07 & 28,141 & 0.64 & 1.07 & 30,845 & 0.86 & 1.05 & 0.00 \\
\hline RL1 & 58,986 & 0.18 & 0.38 & 28,141 & 0.15 & 0.36 & 30,845 & 0.19 & 0.40 & 0.00 \\
\hline RL2 & 58,986 & 0.05 & 0.21 & 28,141 & 0.05 & 0.22 & 30,845 & 0.04 & 0.20 & 0.00 \\
\hline \multicolumn{11}{|l|}{ Individual Physical characteristics } \\
\hline Height $(\mathrm{cm})$ & 58,986 & 155.96 & 10.24 & 28,141 & 155.28 & 11.95 & 30,845 & 156.58 & 8.34 & 0.00 \\
\hline \multicolumn{11}{|l|}{ Temporary shock } \\
\hline Disaster (number of experienced) & 58,986 & 0.39 & 2.57 & 28,141 & 0.15 & 1.69 & 30,845 & 0.61 & 3.15 & 0.00 \\
\hline Log of assistance received & 58,986 & 0.34 & 2.07 & 28,141 & 0.57 & 2.71 & 30,845 & 0.12 & 1.20 & 0.00 \\
\hline \multicolumn{11}{|l|}{ Other control variables } \\
\hline Log of assets & 58,986 & 18.99 & 2.18 & 28,141 & 17.19 & 1.85 & 30,845 & 20,64 & 0.57 & 0.00 \\
\hline Moslem (=1) & 58,986 & 0.90 & 0.30 & 28,141 & 0.90 & 0.30 & 30,845 & 0.90 & 0.30 & 0.48 \\
\hline Javanese $(=1)$ & 58,986 & 0.43 & 0.49 & 28,141 & 0.43 & 0.49 & 30,845 & 0.44 & 0.50 & 0.31 \\
\hline Rural (=1) & 58,986 & 0.44 & 0.50 & 28,141 & 0.47 & 0.50 & 30,845 & 0.41 & 0.49 & 0.00 \\
\hline Age (year) & 58,986 & 36.98 & 15.12 & 28,141 & 36.78 & 15.48 & 30,845 & 37.16 & 14.78 & 0.00 \\
\hline Married (=1) & 58,986 & 0.71 & 0.46 & 28,141 & 0.70 & 0.46 & 30,845 & 0.73 & 0.45 & 0.00 \\
\hline Timepref (1-5, higher more impatient) & 58,986 & 4.33 & 1.11 & 28,141 & 4.43 & 1.03 & 30,845 & 4.24 & 1.17 & 0.00 \\
\hline Education $(0-4$, higher more educated $)$ & 58,986 & 2.13 & 1.15 & 28,141 & 2.01 & 1.15 & 30,845 & 2.23 & 1.13 & 0.00 \\
\hline
\end{tabular}


We categorize possible risk avoidance determinants into two main categories in this study: individual physical characteristics and temporary event/shocks. Variables for the individual physical characteristics are height and weight. We use height (in centimeters) as primary physical attributes and adding weight to the regression as a compliment. The average height is $156 \mathrm{~cm}($ S.D. $10 \mathrm{~cm})$, while the average weight is $56 \mathrm{~kg}$ (S.D. $12 \mathrm{~kg}$ ). We also included the number of natural disasters that the household has encountered, more than just earthquake and flooding as in Cameron and Shah's (2015) paper. IFLS also records the number of belongings of the household (commercial and non-commercial belongings) that were lost as a result of the disaster. Many of the victims of the disaster have also received financial aid. We then used the natural $\log$ of these variables and employed them as additional control variables.

The development of other control variables is relatively standard and relatively straightforward, such as income and employment. Nonetheless, there is a feature "Time Preference" that worth to discuss. The consequence of the risk-loving actions may be influenced by the impatience groups to get an immediate reward. Under the segment called "Time Preference", interviewee was asked to answer a series of questions about the hypothetical money won in a lottery. In this section, there are two games which vary in the time the respondent gets the money (in 1 year in Game 1 and 5 years in Game 2). Then we developed a certain measure of time preference values which range from 1 (very patient) to 5 (very impatient). Here is a sample of question (for a complete set of questions and rules to generate this variable, please see the appendix):

You have won the lottery. You can choose between being paid: 1. Rp1 million today or 2. Rp2 million in 1 year. Which do you choose?

\subsection{Econometrics method}

Our identification strategy exploits the determinants of changing risk preferences overtime. Using OLS, we run the following model, control for fixed effects in subdistricts and also cluster the standard errors at subdistrict level:

$A R A_{i t}=\alpha t+\beta 1 P h C_{i t}+\beta 2$ Shock $_{i t}+\beta 3 X_{i t}+u_{i t}$

$A R A$ is risk-aversion measurement at individual level, $\alpha t$ is the time effect, $P h C$ is a group of physical characteristics variables (height, weight), the Shock is a group for temporary events variables (number of disasters experienced, amount of financial assistance received), $X$ is a group of demographic and geographic characteristics (assets, age, age-square, sex, rural, religion, ethnicity, marital status, education, and time preference), and $u_{i t}$ is the error term which is supposed to follow the normal assumptions.

The novelty of our study is that we use panel data. Many risk-preference analysis is focused on cross-sectional data (e.g. Harrison, Humphrey and Verschoor, 2010) subject to the particular limitations associated with such data. We may provide further suggest to the study of over time risk preference by presenting evidence from a panel data set. Although it is difficult to solve the endogeneity problem in full, we are trying to incorporate shock (number of disasters experienced) that exogenous and unexpected across all households in our estimation.

\section{Empirical results and discussion 3.1 Summary statistics}

Summary statistics by risk preference reveals some important details before we move forward to the regression. To simplify the presentation, Table 3 summarizes the full statistics based on $R A$ (which consists of 5 values) rather than $A R A$ (which includes eight values). Notice that the correlation between ARA and RA is strong (-0.77). From the details in the table, we can see that the majority (58.84 percent) of the population are very risk averse. It also looks like non-Javanese males appear to be more willing to take the risk. 
Table 3. Summary statistics

\begin{tabular}{|c|c|c|c|c|c|c|}
\hline & Average & $\begin{array}{l}\text { Very risk- } \\
\text { averse }\end{array}$ & Risk-averse & Moderate & Risk Loving & $\begin{array}{l}\text { Very risk- } \\
\text { loving }\end{array}$ \\
\hline Height $(\mathrm{cm})$ & 155.96 & 155.32 & 156.21 & 157.06 & 157.51 & 158.82 \\
\hline Weight (kg) & 55.86 & 55.38 & 56.13 & 56.60 & 57.04 & 57.91 \\
\hline Disaster (how often) & 0.39 & 0.35 & 0.46 & 0.45 & 0.36 & 0.41 \\
\hline Log assistance & 0.33 & 0.38 & 0.22 & 0.27 & 0.34 & 0.45 \\
\hline Log assets & 18.99 & 18.75 & 19.49 & 19.30 & 19.34 & 18.80 \\
\hline Moslem (=1) & 0.89 & 0.90 & 0.89 & 0.90 & 0.90 & 0.89 \\
\hline Javanese $(=1)$ & 0.43 & 0.44 & 0.44 & 0.41 & 0.40 & 0.38 \\
\hline Rural (=1) & 0.44 & 0.45 & 0.42 & 0.44 & 0.42 & 0.37 \\
\hline Age (years) & 36.98 & 37.56 & 35.71 & 36.74 & 35.89 & 35.90 \\
\hline Male (=1) & 0.47 & 0.44 & 0.46 & 0.54 & 0.57 & 0.67 \\
\hline Married (=1) & 0.71 & 0.72 & 0.70 & 0.72 & 0.70 & 0.72 \\
\hline \multicolumn{7}{|l|}{ Time preference } \\
\hline$(1-5)$ & 4.33 & 4.48 & 4.10 & 4.14 & 4.03 & 4.15 \\
\hline Education (0-4) & 2.12 & 2.04 & 2.24 & 2.19 & 2.27 & 2.53 \\
\hline Obs(people) & 58986 & 34708 & 10354 & 9503 & 2610 & 1811 \\
\hline Percentage & $100 \%$ & $58.84 \%$ & $17.5 \%$ & $16.11 \%$ & $4.42 \%$ & $3.07 \%$ \\
\hline
\end{tabular}

Notes: These are the mean values except for the number of observations.

Some of the problems surrounding survey data is that people probably do not understand the questions asked (measurement error). In these IFLS4 and IFLS5 data set. The proportion of respondents who have apparently chosen "Don't Know" on risk preference questions at least once is very low (less than 1 per cent in each game). Therefore, the measurement error concerning this problem is negligible.

\subsection{Estimation results}

In Table 4, we present ARA as the dependent variable in the main estimation results. We used several specifications combining physical characteristics, temporary shock and variable control. In column (1) the regressors are physical characteristics, temporary shock, and a group of control variables; column (2) is physical characteristics and temporary shocks; column (3) is physical characteristics and control variables; column (4) is temporary shocks and control variables; column (5) consists only of physical characteristics and, finally; column (6) consists only of temporary shocks.

From all specifications, the dummy year coefficients are negative and statistically significant. Thus, ceteris paribus, the risk preference of our respondents tends to decrease significantly over 2007 and 2014 period. Furthermore, we found that there is a significant correlation between height and risk preference (Table 4 column (5)), and as expected, the direction is negative. As we tried to control other control variables, however, the significance of the physical characteristics decreased (column (1)). We can also see that temporary shock variables on ARA are not substantially associated in all specifications. Next, the calculated male coefficients are negative and significant. Meaning that male tends to be more risk-lover than female.

Another significant estimated coefficient within the control variables is Javanese and rural. Javanese people and people who live in rural area tend to be more risk-averse relative to those who live in the urban area and have non-Javanese ethnicity background. The coefficient for time preference and education are somewhat mixed. It seems that if individuals time preference is increase until category 4 (impatient), they tend to be risk-loving, but for people with very impatient characteristics (category (5)) they become risk-averse. This situation is consistent across all specification and in line with the previous study. Sanjaya (2013) finds that the expected severity of such a disaster suggest that changes in perceptions of background risk are driving the more risk-averse behavior we observe. He conducted standard risk games (using real money) with randomly selected individuals in Indonesia and find that individuals who recently suffered a flood or earthquake exhibit more risk aversion than individuals living in otherwise like villages. The author found that there is limited evidence that shocks and predetermined characteristics can affect risk preference. There is a preliminary indication that risk preference was not only driven by the individual's wealth and demographic factors (that can be easily controlled), but also by the individual's time preference. 
Table 4. Regression result

\begin{tabular}{|c|c|c|c|c|c|c|}
\hline \multirow{2}{*}{ Variables } & $(1)$ & $(2)$ & (3) & (4) & $(5)$ & (6) \\
\hline & ARA & ARA & ARA & ARA & ARA & ARA \\
\hline Dummy 2014 & $\begin{array}{r}-0.0132 * * * \\
(-7.65)\end{array}$ & $\begin{array}{r}-0.0183 * * * \\
(-12.34)\end{array}$ & $\begin{array}{r}-0.0134 * * * \\
(-7.72)\end{array}$ & $\begin{array}{r}-0.0133 * * * \\
(-7.75)\end{array}$ & $\begin{array}{r}-0.0184 * * * \\
(-12.21)\end{array}$ & $\begin{array}{r}-0.0194 * * * \\
(-12.98)\end{array}$ \\
\hline \multicolumn{7}{|l|}{ Physical characteristics } \\
\hline Height & $\begin{array}{r}-0.0001 * * \\
(-2.82)\end{array}$ & $\begin{array}{r}-0.0007 * * * \\
(-15.18)\end{array}$ & $\begin{array}{r}-0.0001 * * \\
(-2.79)\end{array}$ & & $\begin{array}{r}-0.0007 * * * \\
(-15.14)\end{array}$ & \\
\hline Weight & $\begin{array}{r}-0.0000 \\
(-0.66) \\
\end{array}$ & $\begin{array}{r}-0.0001 * * \\
(-2.68)\end{array}$ & $\begin{array}{r}-0.0000 \\
(-0.66) \\
\end{array}$ & & $\begin{array}{r}-0.0001 * * \\
(-2.70)\end{array}$ & \\
\hline \multicolumn{7}{|l|}{ Temporary shock } \\
\hline Disaster & $\begin{array}{r}-0.0001 \\
(-1.20)\end{array}$ & $\begin{array}{r}-0.0001 \\
(-0.95)\end{array}$ & & $\begin{array}{r}-0.0001 \\
(-1.16)\end{array}$ & & $\begin{array}{r}-0.0001 \\
(-0.85)\end{array}$ \\
\hline Log of assistance & $\begin{array}{r}0.0003 \\
(0.57) \\
\end{array}$ & $\begin{array}{r}0.0001 \\
(0.29) \\
\end{array}$ & & $\begin{array}{r}0.0002 \\
(0.56) \\
\end{array}$ & & $\begin{array}{r}0.0001 \\
(0.21) \\
\end{array}$ \\
\hline \multicolumn{7}{|l|}{ Other control variables } \\
\hline Log of assets & $\begin{array}{r}-0.0006 \\
(-1.73)\end{array}$ & & $\begin{array}{r}-0.0006 \\
(-1.70)\end{array}$ & $\begin{array}{r}-0.0007 \\
(-1.77)\end{array}$ & & \\
\hline Moslem & $\begin{array}{r}-0.0020 \\
(-1.41)\end{array}$ & & $\begin{array}{r}-0.0020 \\
(-1.37)\end{array}$ & $\begin{array}{r}-0.0018 \\
(-1.23)\end{array}$ & & \\
\hline Javanese & $\begin{array}{r}0.0032 * \\
(2.03)\end{array}$ & & $\begin{array}{r}0.0033^{*} \\
(2.11)\end{array}$ & $\begin{array}{r}0.0032 * \\
(1.99)\end{array}$ & & \\
\hline Rural & $\begin{array}{r}0.0024^{*} \\
(1.99)\end{array}$ & & $\begin{array}{r}0.0023^{*} \\
(2.01)\end{array}$ & $\begin{array}{r}0.0026^{*} \\
(2.16)\end{array}$ & & \\
\hline Age & $\begin{array}{r}-0.0005 * * * \\
(-4.45)\end{array}$ & & $\begin{array}{r}-0.0005^{* * *} \\
(-4.47)\end{array}$ & $\begin{array}{r}-0.0006^{* * * *} \\
(-4.91)\end{array}$ & & \\
\hline $\mathrm{Age}^{\wedge} 2$ & $\begin{array}{r}0.0000 * * * * \\
(5.85)\end{array}$ & & $\begin{array}{r}0.0000 * * * * \\
(5.91)\end{array}$ & $\begin{array}{r}0.0000^{* * * *} \\
(6.34)\end{array}$ & & \\
\hline Male & $\begin{array}{r}-0.0134 * * * \\
(-14.88)\end{array}$ & & $\begin{array}{r}-0.0134 * * * \\
(-14.87)\end{array}$ & $\begin{array}{r}-0.0149 * * * * \\
(-17.48)\end{array}$ & & \\
\hline Married & $\begin{array}{r}0.0020 \\
(1.96) \\
\end{array}$ & & $\begin{array}{r}0.0020 \\
(1.96) \\
\end{array}$ & $\begin{array}{r}0.0019 \\
(1.87) \\
\end{array}$ & & \\
\hline \multicolumn{7}{|l|}{ Time preference } \\
\hline Patient & $\begin{array}{r}-0.0234 * * * \\
(-8.56)\end{array}$ & & $\begin{array}{r}-0.0234 * * * \\
(-8.58)\end{array}$ & $\begin{array}{r}-0.0234 * * * \\
(-8.54)\end{array}$ & & \\
\hline Somewhat impatient & $\begin{array}{r}-0.0230 * * * \\
(-7.01)\end{array}$ & & $\begin{array}{r}-0.0230 * * * \\
(-7.03)\end{array}$ & $\begin{array}{r}-0.0230 * * * \\
(-7.00)\end{array}$ & & \\
\hline Impatient & $\begin{array}{r}-0.0217 * * * \\
(-6.88)\end{array}$ & & $\begin{array}{r}-0.0217 * * * \\
(-6.90)\end{array}$ & $\begin{array}{r}-0.0217 * * * \\
(-6.88)\end{array}$ & & \\
\hline Very impatient & $\begin{array}{r}0.0159 * * * \\
(4.98)\end{array}$ & & $\begin{array}{r}0.0159 * * * * \\
(4.99)\end{array}$ & $\begin{array}{r}0.0159^{* * * *} \\
(4.98)\end{array}$ & & \\
\hline \multicolumn{7}{|l|}{ Education } \\
\hline Elementary & $\begin{array}{r}0.0053 * * \\
(2.88)\end{array}$ & & $\begin{array}{r}0.0053 * * \\
(2.93)\end{array}$ & $\begin{array}{r}0.0052 * * \\
(2.86)\end{array}$ & & \\
\hline Junior & $\begin{array}{r}0.0027 \\
(1.35)\end{array}$ & & $\begin{array}{r}0.0027 \\
(1.41)\end{array}$ & $\begin{array}{r}0.0026 \\
(1.29)\end{array}$ & & \\
\hline Senior & $\begin{array}{r}-0.0043 \\
(-1.92)\end{array}$ & & $\begin{array}{r}-0.0042 \\
(-1.94)\end{array}$ & $\begin{array}{r}-0.0045^{*} \\
(-2.05)\end{array}$ & & \\
\hline University & $\begin{array}{r}-0.0159 * * * \\
(-6.57)\end{array}$ & & $\begin{array}{r}-0.0159 * * * \\
(-6.61)\end{array}$ & $\begin{array}{r}-0.0163 * * * \\
(-6.81)\end{array}$ & & \\
\hline Constant & $\begin{array}{r}0.1928 * * * \\
(18.13)\end{array}$ & $\begin{array}{r}0.2613 * * * \\
(38.13)\end{array}$ & $\begin{array}{r}0.1925 * * * \\
(17.90)\end{array}$ & $\begin{array}{r}0.1732 * * * \\
(23.65)\end{array}$ & $\begin{array}{r}0.2613 * * * \\
(38.21)\end{array}$ & $\begin{array}{r}0.1543 * * * \\
(196.14)\end{array}$ \\
\hline F test & 736.76 & 65.33 & 705.12 & 731.69 & 108.75 & 56.83 \\
\hline R-square & 0.08 & 0.02 & 0.08 & 0.08 & 0.02 & 0.01 \\
\hline $\mathrm{N}$ & 58,986 & 58,986 & 58,986 & 58,986 & 58,986 & 58,986 \\
\hline
\end{tabular}

Notes: Robust standard errors in parentheses.

The coefficient for education is also significant, but again the result is also mixed. A person with elementary school tends to be risk-averse, but the education level is at the university or equivalent, then he/she tends to be risk loving. 


\section{Conclusion}

In general, our study found that the risk aversion of individual decrease significantly over the periods. This evidence might become a good signal for Indonesia since several studies in developing countries point out the role of risk aversion to the poverty existences. As for the vital role of temporary shocks and physical characteristics in deciding the risk preference of individuals, our observation shows that this is not necessarily the case. In regressions that contain physical characteristics, especially for individual's height, showed significance and correlates negatively with ARA, but then decreased when we control demographic variations and other variables. However, the correlation between being impatient with a low degree of ARA (risk-loving) is also strong, which offer a preliminary indication that the risk preference indeed random.

From the policy perspective, the higher education level can positively influence the household decision by reducing individual risk-aversion. Therefore, improvement of education can contribute to poverty alleviation and economic development, especially within rural areas. Eventually, this study is just a brief introduction to studies on overtime risk preference in Indonesia. We would also suggest for further empirical research to find the best fit instrument(s) that can purge the potential endogenous variables in the model.

\section{References}

Alós-Ferrer, C. and Strack, F. (2014), "From dual processes to multiple selves: Implications for economic behavior", Journal of Economic Psychology, Vol. 41, pp. 1-11.

Cameron, L. and Shah, M. (2015), "Risk-taking behavior in the wake of natural disasters", Journal of Human Resources, Vol. 50 No. 2, pp. 484-515.

Cipollone, A. and D'Ippoliti, C. (2011), “Women's employment: Joining explanations based on individual characteristics and on contextual factors", American Journal of Economics and Sociology, Vol. 70 No. 3, pp. $756-783$.

Eckel, C.C. (2019), “Measuring individual risk preferences", IZA World of Labor, No. June, pp. 1-11.

Eckel, C.C., El-Gamal, M.A. and Wilson, R.K. (2009), "Risk loving after the storm: A Bayesian-Network study of Hurricane Katrina evacuees”, Journal of Economic Behavior and Organization, Vol. 69 No. 2, pp. 110 124.

Fudenberg, D., Levine, D.K. and Maniadis, Z. (2014), “An approximate dual-self model and paradoxes of choice under risk", Journal of Economic Psychology, Elsevier B.V., Vol. 41, pp. 55-67.

Harrison, G.W., Humphrey, S.J. and Verschoor, A. (2010), "Choice under uncertainty: Evidence from ethiopia, India and Uganda", Economic Journal, Vol. 120 No. 543, pp. 80-104.

Levin, I.P., Weller, J.A., Pederson, A.A. and Harshman, L.A. (2007), "Age-related differences in adaptive decision making: Sensitivity to expected value in risky choice", Age-Related Differences in Adaptive Decision Making: Sensitivity to Expected Value in Risky Choice, Vol. 2 No. 4, pp. 225-233.

Permani, R. (2011), Revisiting the Link between Maternal Employment and School-Aged Children Health Status in Developing Countries : An Instrumental Variable Approach, Research Paper No. 2011-21.

Pratt, J. w. (1964), "Risk Aversion in the Small and in the Large", Econometrica, Vol. 32 No. 1, pp. 122-136.

Sakha, S. (2019), "Determinants of risk aversion over time: Experimental evidence from rural Thailand", Journal of Behavioral and Experimental Economics, Vol. 80, pp. 184-198.

Sanjaya, M. (2013), "On the source of risk aversion in Indonesia using micro data 2007", Economics Discussion Papers, Vol. 2013-33, pp. 0-31.

Schildberg-Hörisch, H. (2018), “Are Risk Preferences Stable?”, Journal of Economic Perspectives, Vol. 32 No. 2, pp. 135-154. 


\section{Appendix}

Questions on risk preference in IFLS4 and IFLS5

SECTION SI: RISK AND TIME PREFERENCES

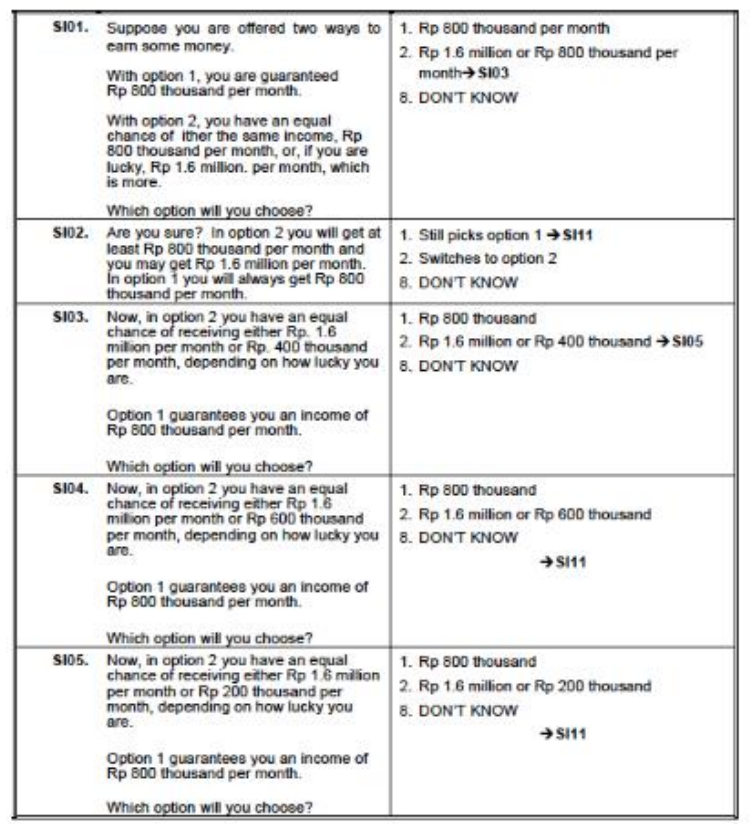

\begin{tabular}{|c|c|c|}
\hline Sl11. & $\begin{array}{l}\text { Suppoee you are offered two waye to } \\
\text { eam income. } \\
\text { With opsion } 1 \text {, you are guaranteed an } \\
\text { income of Rp } 4 \text { million per month. } \\
\text { With option } 2 \text {, you have an equal } \\
\text { chance of earming either the samme } \\
\text { income, Rp } 4 \text { million per month, or, it } \\
\text { you are unlucky, Rp } 2 \text { million per } \\
\text { month, which is less. } \\
\text { Which option will you choose? }\end{array}$ & $\begin{array}{l}\text { 1. Rp } 4 \text { million } \rightarrow \text { SI13 } \\
\text { 2. Rp } 4 \text { million or Rp } 2 \text { million } \\
\text { 8. DONT KNOW }\end{array}$ \\
\hline $\mathbf{s 1 1 2 .}$ & 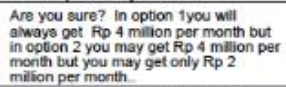 & $\begin{array}{l}\text { 1. Still picks option } 1 \rightarrow \text { S121 } \\
\text { 2. Switches to option } 2 \\
\text { 8. DONT KNOW }\end{array}$ \\
\hline S113. & $\begin{array}{l}\text { Now, in option } 2 \text { you have an equal } \\
\text { chance of receiving eather Rp } 12 \text { million } \\
\text { per month or nothing, depending on } \\
\text { how luchy you are. } \\
\text { Option } 1 \text { gusarantees you an income of } \\
\text { Rp } 4 \text { million per month. } \\
\text { Which option will you choose? }\end{array}$ & $\begin{array}{l}\text { 1. Rp } 4 \text { million } \\
\text { 2. Rp } 12 \text { millon or Rp } 0 \rightarrow \text { SHS } \\
\text { 8. DONT KNOW }\end{array}$ \\
\hline S114. & $\begin{array}{l}\text { Now, in option } 2 \text { you have an equal } \\
\text { chance of receiving ealher Rp } 8 \text { million } \\
\text { per month or Rp } 2 \text { million per month, } \\
\text { depending on how lucky you are. } \\
\text { Opton } 1 \text { guaranteos you an income of } \\
\text { Rp } 4 \text { million per month. } \\
\text { Which option will you chooee? }\end{array}$ & $\begin{array}{l}\text { 1. Rp } 4 \text { million } \\
\text { 2. Rp } 8 \text { million or Rp } 2 \text { malion } \\
\text { 8. DONT KNOW } \rightarrow \text { SI21 }\end{array}$ \\
\hline S116. & 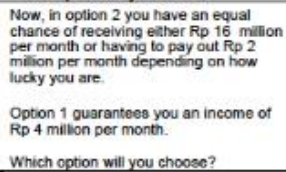 & $\begin{array}{l}\text { 1. Rp } 4 \text { million } \\
\text { 2. Rp } 16 \text { milion or -Rp } 2 \text { millor } \\
\text { 8. DONT KNOW } \rightarrow \text { SI24 }\end{array}$ \\
\hline
\end{tabular}

Questions on time preference in IFLS4 and IFLS5

SECTION SI: RISK AND TIME PREFERENCES

\begin{tabular}{|c|c|c|c|}
\hline \multirow[t]{6}{*}{ \$121. } & \multicolumn{3}{|l|}{ You have won the lottery. You can choose between being paid } \\
\hline & $\begin{array}{l}\text { A. } 1 \text {. Rp } 1 \text { million today or } 2 \text { Rp } 1 \text { million in } 1 \text { year } \\
\text { Which do you choose? }\end{array}$ & A 1. Rp 1 million today $\rightarrow B$ & 2. Rp 1 million in 1 year $\rightarrow E$ \\
\hline & $\begin{array}{l}\text { B. } 1 \text {. Rp } 1 \text { million today or } 2 \text {. Rp } 3 \text { million in } 1 \text { year } \\
\text { Which do you choose? }\end{array}$ & B. 1. Rp 1 million today $\rightarrow C$ & 2. Rp 3 million in 1 year $\rightarrow D$ \\
\hline & $\begin{array}{l}\text { C. } 1 \text {. Rp } 1 \text { million today or } 2 \text { Rp } 6 \text { million in } 1 \text { year } \\
\text { Which do you choose? }\end{array}$ & C. 1. Rp 1 million today $\rightarrow \mathbf{S} 122$ & 2. Rp 6 million in 1 year $\rightarrow \mathbf{S I 2 2}$ \\
\hline & $\begin{array}{l}\text { D. } 1 \text {. Rp } 1 \text { million today or } 2 \text {. Rp } 2 \text { million in } 1 \text { year } \\
\text { Which do you choose? }\end{array}$ & D. 1. Rp 1 million today $\rightarrow \mathbf{S I} 22$ & 2. Rp 2 million in 1 year $\rightarrow \mathbf{S I 2 2}$ \\
\hline & $\begin{array}{l}\text { E. Are you sure you prefer the same amount in the future although you get the same } \\
\text { amount if you do not wait? }\end{array}$ & E. 1. Yes $\rightarrow \mathbf{S I n 2}$ & 3. No prefer Rp 1 million today $\rightarrow B$ \\
\hline \multirow[t]{6}{*}{$\mathbf{s 1 2 2 .}$} & \multicolumn{3}{|l|}{ You have won the lottery. You can choose between being paid } \\
\hline & $\begin{array}{l}\text { A. } 1 \text {. Rp } 1 \text { million today or } 2 \text {. Rp } 500,000 \text { in } 5 \text { years } \\
\text { Which do you choose? }\end{array}$ & A 1. Rp 1 million today $\rightarrow B$ & 2. Rp 0.5 million in 5 years $\rightarrow E$ \\
\hline & $\begin{array}{l}\text { B. 1.Rp } 1 \text { million today or } 2 \text {. Rp } 4 \text { million in } 5 \text { years } \\
\text { Which do you choose? }\end{array}$ & B. 1. Rp 1 million today $\rightarrow C$ & 2. Rp 4 million in 5 years $\rightarrow D$ \\
\hline & $\begin{array}{l}\text { C. } 1 \text {. Rp } 1 \text { million today or } 2 \text { Rp } 10 \text { million in } 5 \text { years } \\
\text { Which do you choose? }\end{array}$ & C. 1. Rp 1 million today $\rightarrow$ SECTION TR & 2. Rp 10 million in 5 years $\rightarrow$ SECTION TR \\
\hline & $\begin{array}{l}\text { D. } 1 \text {. Rp } 1 \text { million today or } 2 \text { Rp } 2 \text { million in } 5 \text { years } \\
\text { Which do you choose? }\end{array}$ & D. 1. Rp 1 million today $\rightarrow$ SECTION TR & 2. Rp 2 million in 5 years $\rightarrow$ SECTION TR \\
\hline & $\begin{array}{l}\text { E. Are you sure you prefer the smaller amount in the future rather than a larger } \\
\text { amount without warting? }\end{array}$ & E. 1. Yes $\rightarrow F$ & 3. No prefer Rp 1 million today $\rightarrow B$ \\
\hline
\end{tabular}

Possible path taken by respondent 


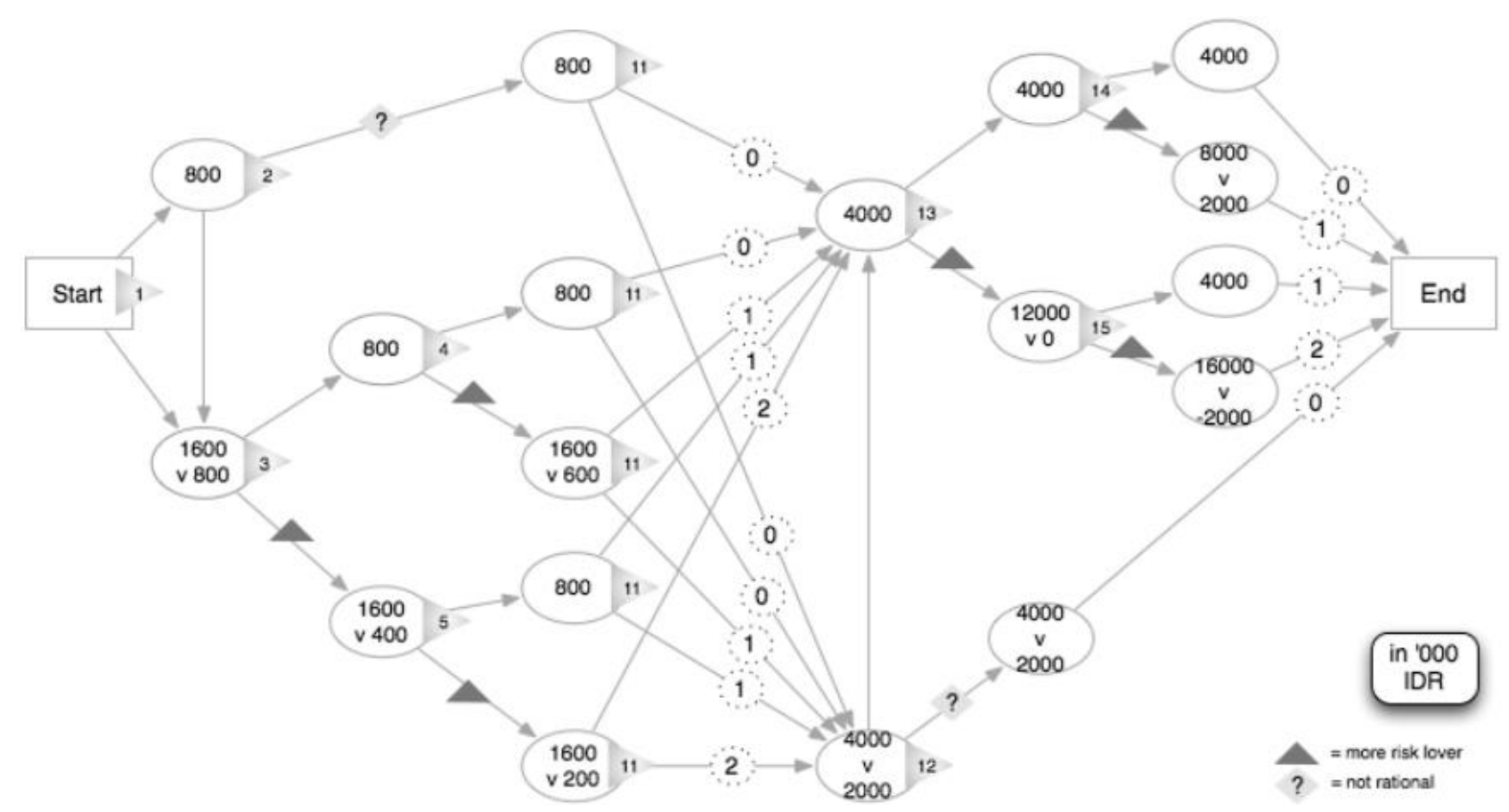

Source: adapted from Sanjaya (2013)

Example of respondent's path

\begin{tabular}{|c|c|c|c|c|c|}
\hline \multirow{2}{*}{ Path } & \multicolumn{2}{|l|}{ Game 1} & \multicolumn{2}{|l|}{ Game 2} & \multirow{2}{*}{$\begin{array}{c}R A= \\
\text { Score 1+ } \\
\text { Score } 2\end{array}$} \\
\hline & Choice & Score 1 & Choice & Score 2 & \\
\hline 1 & $\begin{array}{c}\text { SI01 }=2 ; \text { SI03 }=2 ; \\
\text { SI05 }=2\end{array}$ & 2 & $\begin{array}{c}\text { SI11 }=1 ; \text { SI13=2; } \\
\text { SI15=2 }\end{array}$ & 2 & 4 \\
\hline 2 & $\begin{array}{c}\mathrm{SI01}=2 ; \mathrm{SIO} 3=1 ; \\
\mathrm{SIO}=4=2\end{array}$ & 1 & $\begin{array}{c}\text { SI11 }=1 ; \text { SI13=2; } \\
\text { SI15=1 }\end{array}$ & 1 & 2 \\
\hline 3 & $\begin{array}{l}\mathrm{SI01}=1 ; \mathrm{SIO}=2 ; \\
\text { SI03 }=2 ; \mathrm{SI05}=1\end{array}$ & 1 & $\mathrm{SI} 11=2 ; \mathrm{SI} 12=1$ & 0 & 1 \\
\hline 4 & $\begin{array}{c}\text { SI01 }=2 ; \text { SI03 }=1 ; \\
\text { SIO4=1 }\end{array}$ & 0 & $\begin{array}{l}\text { SI11=2; SI12=2; } \\
\text { SI13=1; SI14=1 }\end{array}$ & 0 & 0 \\
\hline$\vdots$ & $\vdots$ & $\vdots$ & $\vdots$ & $\vdots$ & $\vdots$ \\
\hline
\end{tabular}

Note: there is two mistranslations in question SI12: a) "still picks option 1" should be read "still picks option 2"; b) "switches to option 2" should be read "switch to option 1 ". Red means that the respondent took the risky choice

Constructing time preference

\begin{tabular}{llcc}
\hline Respondent's choice & \multicolumn{1}{c}{ Forgone amount } & Time preference & Definition \\
\hline \hline Rp1 million in 1 year & Rp1 million today & 1 & Very patient \\
Rp2 million in 1 year & Rp1 million today & 2 & Patient \\
Rp1 million today & Rp2 million in 1 year & 3 & Somewhat impatient \\
Rp6 million in 1 year & Rp1 million today & 4 & Impatient \\
Rp1 million today & Rp6 million in 1 year & 5 & Very impatient \\
\hline
\end{tabular}

Note: impatience was constructed based on Game 1 (question SI21) 